\title{
The effect of sucrose on the development of hybrid walnut microcuttings (Juglans nigra $x$ Juglans regia). Consequences on their survival during acclimatization
}

\author{
D Chenevard 1, C Jay-Allemand 2, M Gendraud 1, JS Frossard 1*
}

1 Unité associée Bioclimatologie-PIAF (INRA - université Blaise-Pascal), domaine de Crouelle, 63039 Clermont-Ferrand cedex 02;

2 INRA, station d'amélioration des arbres forestiers, 45160 Ardon, France

(Received 28 October 1993; accepted 5 August 1994)

Summary - We studied the effect of sucrose concentration in the root-development medium on the formation of adventitious roots and survival of microcuttings during acclimatization in 2 interspecific hybrid walnut (Juglans nigra ${ }^{\circ} 23 \times J$ regia) clones. Sucrose increased the rooting percentage (fig 1 ), the number of adventitious roots (fig 2A) and the dry-matter content (table I) per rooted shoot. These effects were due to the energy properties of sucrose rather than to its osmotic function. High sucrose concentrations in the root-development medium (> $20 \mathrm{~g}^{-1}$ ) resulted in a high soluble carbohydrate content in the plantlets (fig 3), mainly located in roots and callus. The 2 clones showed different capacities in rooting and growth. Survival of microcuttings during acclimatization was not directly influenced by the sucrose concentration (fig 5) but was correlated with the number of adventitious roots (fig $6 \mathrm{~A}$ ) as well as with the number of leaves (fig $6 \mathrm{~B}$ ) present at the time of transfer to the growth chamber for each individual plant.

walnut / rooting / sucrose / micropropagation / acclimatization / survival

Résumé - Rôle du saccharose sur le développement des microboutures de noyers hybrides (Juglans nigra $\times$ Juglans regia). Conséquences sur leur taux de survie en acclimatation. Nous avons étudié l'effet de la concentration en saccharose dans le milieu de développement racinaire sur la formation de racines adventives et la survie de 2 clones d'hybrides interspécifiques de noyer (Juglans nigra 23 x Juglans regia). Les expériences montrent que l'enracinement nécessite la présence de saccharose dans le milieu (fig 1). Le saccharose augmente à la fois le taux d'enracinement, le nombre de

* Correspondence and reprints 
racines adventives (fig 2A) et la quantité de matière sèche (tableau l) par pousse enracinée. Cet effet du saccharose est à relier à ses propriétés énergétiques plus qu'à son rôle osmotique. Les concentrations élevées en saccharose dans le milieu de développement $\left(>20 \mathrm{~g} \mathrm{H}^{-1}\right)$ induisent aussi une teneur élevée en sucres solubles dans les pousses enracinées (fig 3), essentiellement des racines et du cal. Les 2 clones montrent des différences d'enracinement et de croissance. La concentration en saccharose dans le milieu de développement n'a pas d'effet sur la survie des microboutures pendant la phase d'acclimatation. La survie des pousses enracinées des 2 clones augmente avec le nombre de racines adventives (fig $6 A$ ) et avec le nombre de feuilles étalées (fig 6B) présentes au moment de la phase de transfert en chambre climatisée.

noyer / enracinement / saccharose / micropropagation / acclimatation / survie

\section{INTRODUCTION}

Widespread use of micropropagation to produce hybrid walnut plantlets has been limited by the low survival of shoots cultured in vitro during acclimatization. In vitro culture conditions considerably alter the morphological and physiological features of plantlets compared to plants grown from seeds. The epicuticle of the leaves is poorly developed and their stomata are not functional (Wardle et al, 1979). The cultured plantlets are heterotrophic and, in addition to photosynthesis, their energy requirement is largely covered by the carbohydrates from the culture medium. Numerous studies on asparagus (Hasegawa et al, 1973) and rose (Hasegawa, 1980) have shown that certain factors of the in vitro culture medium (cytokinins, salt concentration) can affect survival during the acclimatization phase. In Clematis, a low carbohydrate concentration in the medium increases survival (Lees et al, 1991). Furthermore, it should be noted that a low carbohydrate concentration enhances the photosynthetic ability but that carbohydrates are also required for rooting in rose (Hyndman et al, 1982) and apple (Pua and Chong, 1985).

This paper is mainly devoted to study the effect of sucrose concentration in the rootdevelopment medium on morphology and survival during acclimatization of hybrid walnut microcuttings.

\section{MATERIALS AND METHODS}

\section{Plantlet production}

The 2 clones used in this study, D152 and M41, are interspecific walnut hybrids (Juglans nigra $\mathrm{n}^{\circ} 23 \times J$ regia). They were established from 2 different embryonic axes isolated axenically (JayAllemand and Cornu, 1986) in 2 hybrid walnuts. The shoots were cultured on DKW gelified medium (Driver and Kuniyuki, 1984) containing $4.4 \mu \mathrm{M}$ benzyl adenine and $0.005 \mu \mathrm{M}$ indole butyric acid. The shoots, ranging from 20 to 30 $\mathrm{mm}$ in length, were induced to root on DKW medium diluted to $1: 4$ containing $24.6 \mu \mathrm{M}$ indole butyric acid and $30 \mathrm{gol}-1$ sucrose. The cultures were kept in the dark for $5 \mathrm{~d}$. After this phase, the shoots were transplanted on a hormone-free medium, composed of a vermiculite/DKW mixture $(5: 4 \mathrm{v} / \mathrm{v})$ diluted to $1: 4$ containing sucrose (Jay-Allemand et al, 1992). The sucrose concentrations ranged between 0 and $40 \mathrm{~g}^{\circ} \mathbf{l}^{-1}$. All the experiments were conducted in a growth chamber at $28 / 25 \pm 1^{\circ} \mathrm{C}$ (day/night) with a $16 \mathrm{~h}$ daylength and $40 \mu \mathrm{mol} \cdot \mathrm{m}^{-2} \cdot \mathrm{s}^{-1}$ photosynthetically active radiation (PAR). The rooting percentage, the number of roots, the total length of the root system, the number of mature leaves and the height of the rooted plantlets were determined after 3 weeks in the root-development medium before the acclimatization phase.

\section{Acclimatization}

The acclimatization phase lasted $28 \mathrm{~d}$ and was carried out in a growth chamber. During the first $14 \mathrm{~d}$, humidity was kept high by means of a mist 
system (Defensor), after which the relative humidity was progressively reduced, reaching $70 \%$ at the end of the acclimatization phase. The temperature was $28 / 25 \pm 1^{\circ} \mathrm{C}$. The photoperiod was a $16 \mathrm{~h}$ day with $50 \mu \mathrm{mol} \cdot \mathrm{m}^{-2} \mathrm{~s}^{-1}$ PAR. The rooted plantlets were transferred to a substrate containing vermiculite, sand and potting compost $(2: 1: 1, v / v / v)$. No fertilizer was used. Survival was measured at the end of the acclimatization phase (28 d). A plant was considered to be acclimatized when new leaves had been formed and if there was no necrotic tissue in the apical bud.

\section{Dry matter and biochemical assays}

Five plantlets per treatment were collected at random after 3 weeks in the root-development medium. The plantlets were dissected into roots, callus (base of shoots soaking in the auxin treatment), stem and leaves. These differents parts were frozen immediately in liquid nitrogen and freeze-dried (Frossard and Friaud, 1989). The dry matter content of the different parts of each plantlet was then determined. For each sample, the dry matter was ground in a methanol/chloroform $/$ water $(12: 5: 3 \mathrm{v} / \mathrm{v} / \mathrm{v})$ mixture for $30 \mathrm{~min}$ at room temperature and centrifuged for $20 \mathrm{~min}$ at $12000 \mathrm{~g}$. This step was repeated once more (Dickson, 1979).

The collected and purified supernatants were used for glucose, fructose and sucrose determination. The pellet was treated with $0.02 \mathrm{~N}$ $\mathrm{NaOH}$ and placed in a water bath at $90^{\circ} \mathrm{C}$ for $30 \mathrm{~min}$ to make the starch soluble. The starch was then hydrolysed to glucose by $\alpha$-amyloglucosidase. Assays of the soluble sugars (glucose, fructose and sucrose) were performed by the enzyme method described by Boehringer (1984).

\section{Data analysis}

The effects of the different concentrations of sucrose on the morphology of rooted plantlets for each clone were analysed by a multiple comparison test of the means (Newman and Keuls test). The results expressed as a percentage (rooting and survival) were compared with a $\chi^{2}$. test. The relationships between plant morphology and survival were determined by the corelation coefficient of Spearman $\left(R_{\mathrm{s}}\right)$.

\section{RESULTS}

\section{Effect of sucrose on development of the explant}

Sucrose concentration in the root-development medium affected the rooting percentage (fig 1). In both clones, rooting increased strongly at $10 \mathrm{gel}^{-1}$ sucrose as compared to medium without sucrose $(+46 \%$ in D152 and $+59 \%$ in M41). When the concentration of sucrose was increased from 10 to $40 \mathrm{~g}^{\bullet-1}$, no significant change in rooting percentage was observed in clone M41 whereas it rose by $41 \%$ in $\mathrm{D} 152$. The highest rooting percentage for both clones was obtained on

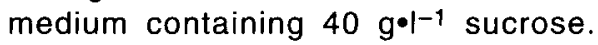
Sucrose is also required in the root-development medium for the promotion of root number (fig 2A). There was a 2.6- and 4.8fold increase in the number of roots per rooted shoot cultured at $30 \mathrm{~g}^{-1}$ for clones M41 and D152, respectively, compared with shoots cultured without sucrose. Thus, the root number formed per hybrid walnut shoot varies according to the clone and the sucrose concentration.

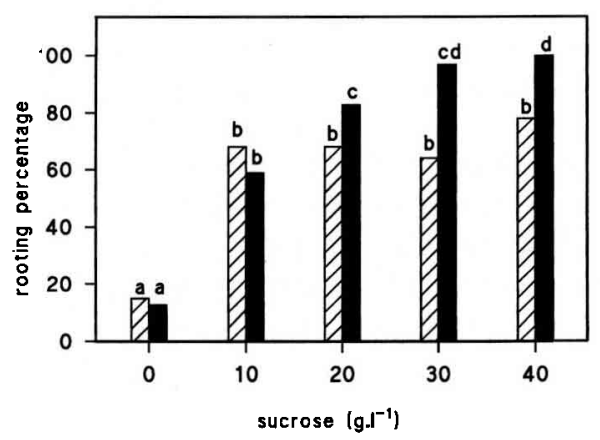

Fig 1. Effect of sucrose concentration in the root-development medium on the rooting percentage of 2 hybrid walnut $\left(J\right.$ nigra $n^{\circ} 23 \times J$ regia) clones M41 and D152 after $21 \mathrm{~d}$ (D152 $n=$ $34, \mathrm{M} 410 n=36)$. Values followed by the same letter are not significantly different $\left(\chi^{2}\right.$ test at the $\alpha=5 \%$ level). 

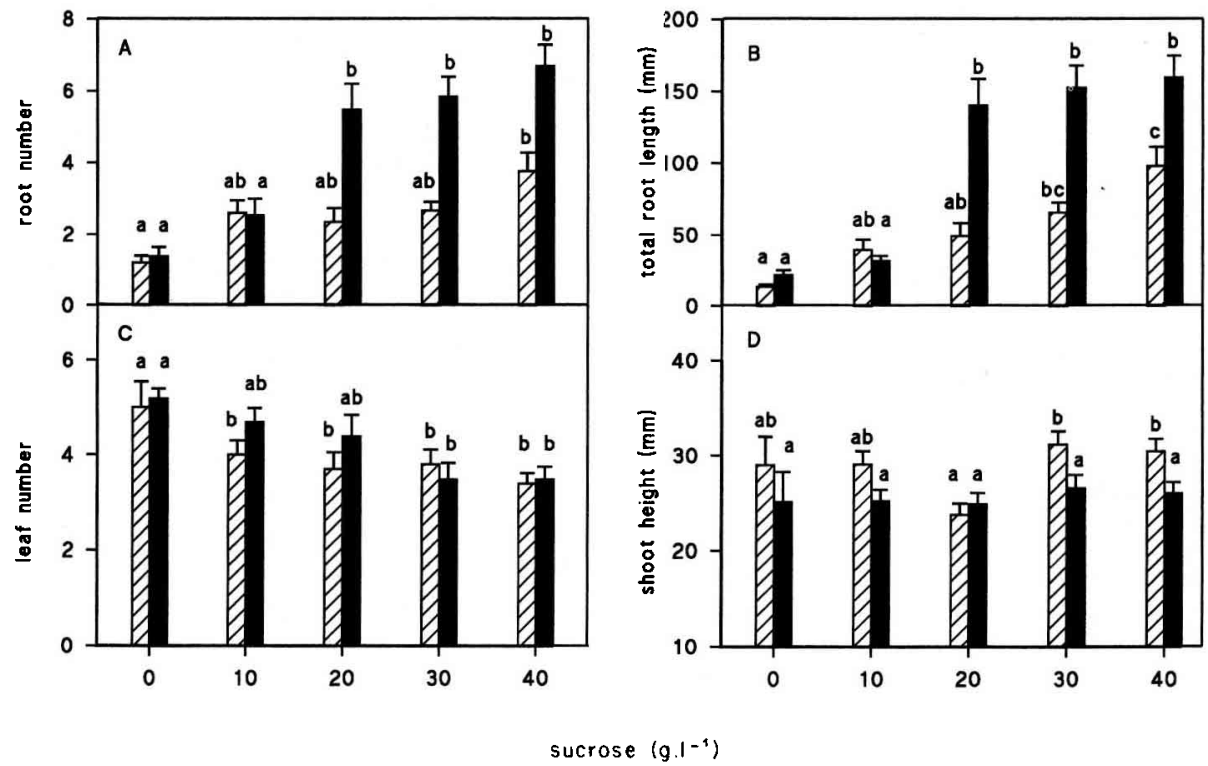

Fig 2. Effect of sucrose concentration in the root-development medium on the average root number (A), the total length of the roots (B), the average leaf number $(C)$ and height (D) per rooted plantlet of 2 hybrid walnut ( $J$ nigra $\mathrm{n}^{\circ} 23 \times J$ regia) clones $\mathrm{M} 41$ and D152 after $21 \mathrm{~d}$ (D152, M41 $\mathbb{Z}$ ). Values followed by the same letter are not significantly different ( $\alpha=5 \%$ average root, total length root and height, $\alpha=$ $10 \%$ leaf number). Results are shown with SE bars.

High sucrose concentrations in the rootdevelopment medium significantly increased the length of the root system (fig 2B). Stem length was not affected by variations in sucrose concentration (fig 2D), being 29 and $26 \mathrm{~mm}$ for D152 and M41, respectively. The number of mature leaves per rooted shoot decreased in both clones with high sucrose concentrations (fig $2 \mathrm{C}$ ).

The dry matter increased in the 2 hybrid walnut clones cultured on a medium containing $30 \mathrm{~g} \cdot \mathrm{I}^{-1}$ sucrose and was twofold greater than on a medium without sucrose (table I). Dry matter accumulated mainly in the roots and the callus of the plantlets cultured on the medium with a concentration of $10 \mathrm{~g} \cdot \mathrm{l}^{-1}$ of sucrose and higher. The shoots of the clone M41 cultured on a medium containing $40 \mathrm{~g} \mathrm{I}^{-1}$ sucrose accu- mulated $65 \%$ of dry matter in the callus whereas it represented only $51 \%$ in the clone D152 cultured in the same conditions.

\section{Effect of sucrose in the medium on plant carbohydrate content}

The increase in dry matter was associated with a rise in soluble carbohydrate content (glucose, fructose and sucrose) within the plantlet (fig 3), mainly in the roots, although clone M41 also accumulated soluble carbohydrate in the callus. The soluble carbohydrate content of the aerial structure (stem and leaves) seemed to be less affected by the sucrose concentration in the root-development medium than the root system. 
Table 1. Effect of sucrose concentration in the root-development medium on dry matter distribution after $21 \mathrm{~d}$.

\begin{tabular}{|c|c|c|c|c|c|}
\hline \multirow[t]{2}{*}{ Clone } & & & Sucrose $\left(g^{\bullet-1}\right)$ & \multirow[b]{2}{*}{30} & \multirow[b]{2}{*}{40} \\
\hline & 0 & 10 & 20 & & \\
\hline- & & - & $\cdots-$ & & \\
\hline \multicolumn{6}{|l|}{$M 41$} \\
\hline Roots & nd & $5 \pm 1.3^{a}$ & $11 \pm 4.6^{a b}$ & $15 \pm 0.5 b^{c}$ & $22 \pm 2.7^{c}$ \\
\hline Callus & $17 \pm 1.1^{\mathrm{a}}$ & $26 \pm 3.2^{\mathrm{a}}$ & $47 \pm 6.6^{b}$ & $72 \pm 12.3^{c}$ & $84 \pm 6.2^{c}$ \\
\hline Stem & $6 \pm 1.1^{a}$ & $8 \pm 1.1^{\mathrm{ab}}$ & $6 \pm 0.8^{a}$ & $11 \pm 1.5^{b}$ & $11 \pm 1.9^{b}$ \\
\hline Leaves & $16 \pm 2.1^{\mathrm{ab}}$ & $13 \pm 1.4^{\mathrm{a}}$ & $14 \pm 2.3^{a}$ & $19 \pm 1.4^{b}$ & $13 \pm 1.3^{a}$ \\
\hline Plantlet & $39 \pm 3.4^{a}$ & $52 \pm 4.7^{a}$ & $79 \pm 9.1^{b}$ & $117 \pm 10.5^{\mathrm{c}}$ & $130 \pm 8^{c}$ \\
\hline \multicolumn{6}{|l|}{$D 152$} \\
\hline Roots & nd & $2 \pm 0.9^{\mathrm{a}}$ & $14 \pm 3.2^{\mathrm{ab}}$ & $28 \pm 2.6^{b}$ & $29 \pm 10.1^{b}$ \\
\hline Callus & $16 \pm 1.8^{a}$ & $36 \pm 3.1^{\mathrm{ab}}$ & $38 \pm 4.0^{b}$ & $44 \pm 3.7^{b}$ & $47 \pm 6.4^{b}$ \\
\hline Stem & $6 \pm 0.8^{a}$ & $9 \pm 1.2^{\mathrm{a}}$ & $7 \pm 0.6^{a}$ & $7 \pm 0.6^{a}$ & $8 \pm 0.9^{a}$ \\
\hline Leaves & $11 \pm 2.7^{a}$ & $10 \pm 1.7^{a}$ & $12 \pm 3.5^{a}$ & $7 \pm 0.9^{a}$ & $9 \pm 1.9^{a}$ \\
\hline Plantlet & $33 \pm 4.5^{\mathrm{a}}$ & $57 \pm 3.4 \mathrm{ab}$ & $72 \pm 8.1^{b}$ & $86 \pm 3.6^{b}$ & $92 \pm 17.9^{b}$ \\
\hline
\end{tabular}

Values followed by the same letter are not significantly different $(n=5, \alpha=5 \%)$. Mean \pm SE are indicated. It was not possible to determine root dry matter content for the sucrose-free treatment.

The starch content of the plantlets was generally low (fig 4) except in the callus of clone M41. However, because of a strong increase of dry matter in the callus, the amount of soluble carbohydrates in the shoots of clone M41 was greater than that in D152 shoots (twice as high as from a concentration of $20 \mathrm{~g}^{\circ-1}$ sucrose).

\section{Relationship between sucrose, morphological features and survival}

The survival of the rooted shoots did not differ according to sucrose concentrations in the root-development medium (fig 5). However, it was variable (from 60 to $100 \%$ ).

An improved survival may have been related to certain morphological features, in particular the number of adventitious roots (fig 6A) and the number of leaves (fig 6B) at transplanting. Irrespective of the sucrose concentration in the development medium, the plantlets of clone M41, with more than 4 roots, had a survival rate of $94 \%$, whereas only $63 \%$ of those with fewer than 2 roots survived. The same pattern was observed in clone D152. The correlation coefficient $\left(R_{\mathrm{s}}\right)$ between survival and the number of adventitious roots was 0.21 and 0.22 for clones M41 $(n=61)$ and D152 $(n=74)$, respectively, with $a=5 \%$. There was also a good correlation between the survival of rooted shoots and the number of adult leaves at transplanting $\left(\mathrm{M} 41, R_{\mathrm{S}}=0.24, \mathrm{D} 152, R_{\mathrm{S}}=\right.$ 0.45 with $a=5 \%$ ).

\section{DISCUSSION}

Sucrose in the root-development medium is one of the major factors for both obtaining a high rooting percentage and promoting root elongation. The role of sucrose in root- 
ing is more closely linked to the energy supplies than to its osmotic properties, as observed by Hyndman et al (1982) in rose shoots. When sucrose was replaced in the development medium by mannitol (which has the same osmotic potential, $p=2.2$ bar), the shoots of clone D152 did not form roots (unpublished results). This finding is simi-

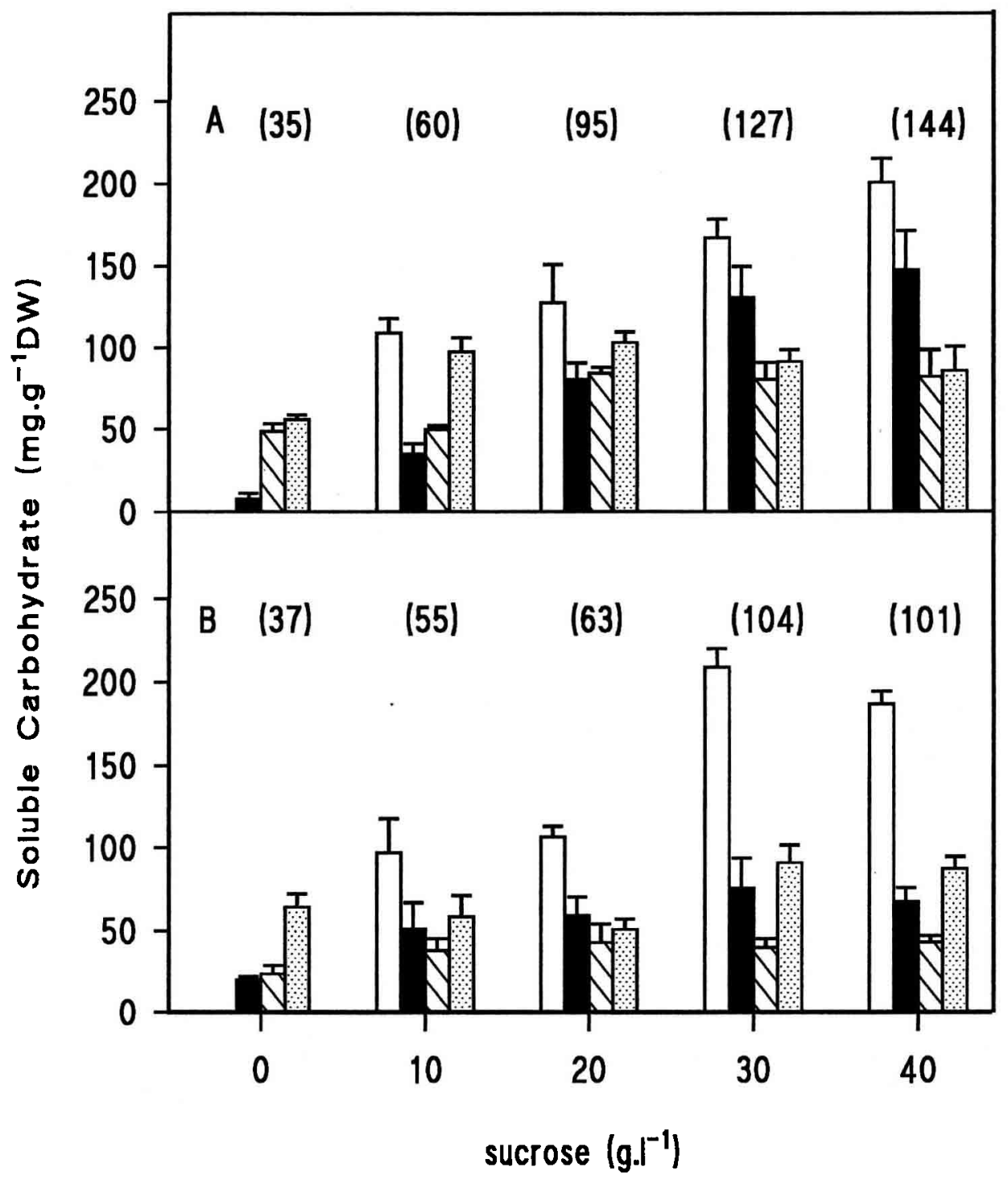

Fig 3. Effect of sucrose concentration in the root-development medium on the soluble carbohydrate content: glucose + fructose + sucrose in the differents parts of the plantlet roots $\square$, callus $\mathbf{D}$,

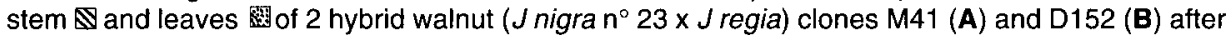
$21 \mathrm{~d}$. The values between brackets are the soluble carbohydrate contents of the whole plantlet $\left(\mathrm{mg}^{\bullet} \mathrm{g}^{-1} \mathrm{DW}\right)$. Results are shown with SE bars $(n=5)$. 
lar to the observations of Greenwood and Berlyn (1973), who also showed that sucrose could not be replaced by osmotic agents such as mannitol or methyl- $\alpha$-D-glu- copyranoside in Pinus lambertiana cuttings. The energy requirements of in vitro plants are mainly covered by the sucrose taken up from the medium. Therefore, it can be

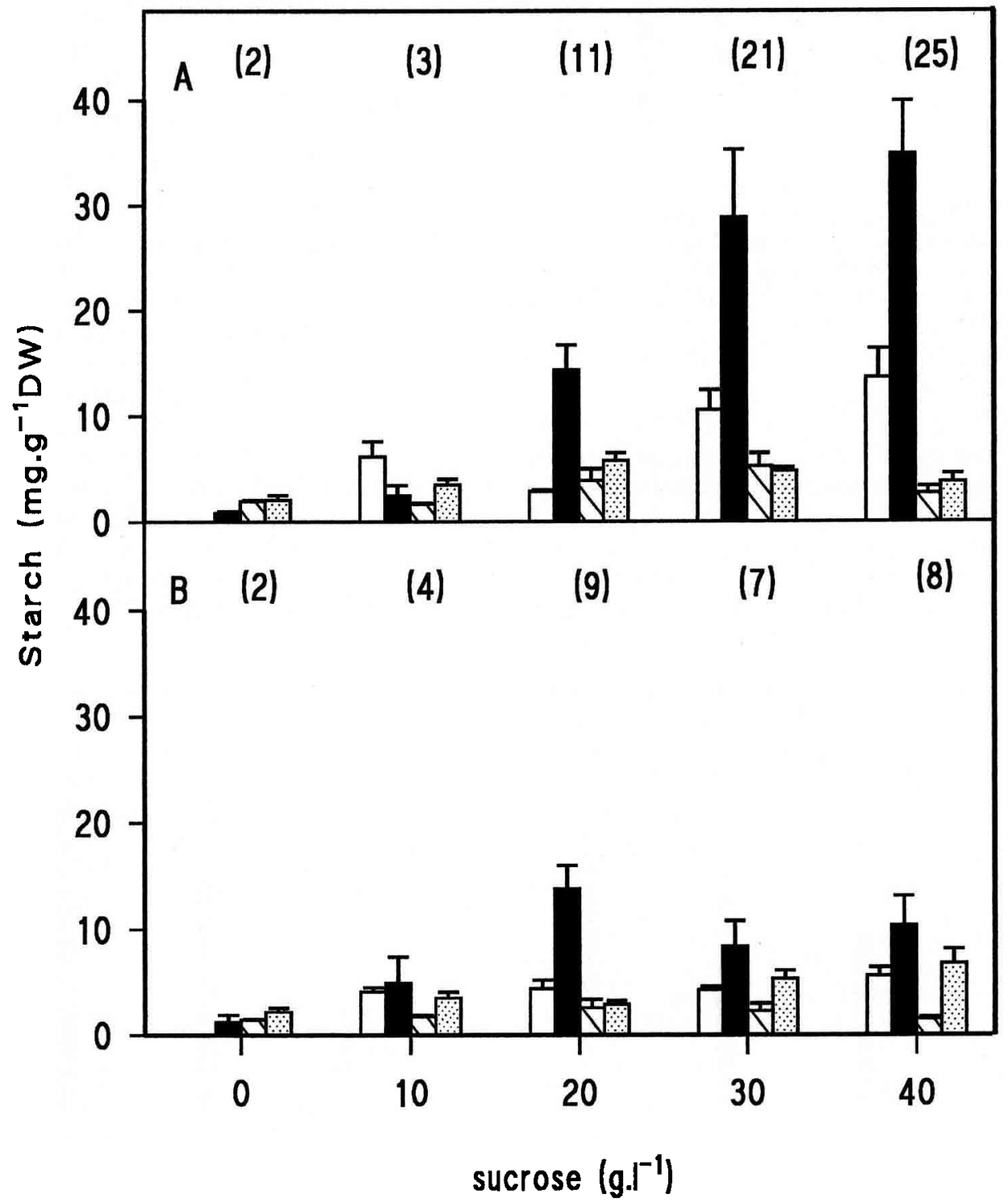

Fig 4. Effect of sucrose concentration in the root-development medium on the starch content in the dif-

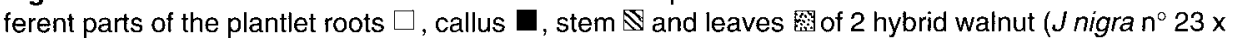
$J$ regia) clones M41 (A) and D152 (B) after $21 \mathrm{~d}$. The values between brackets are the starch contents of the whole plantlet (mg*g-1 DW). Results are shown with SE bars $(n=5)$. 


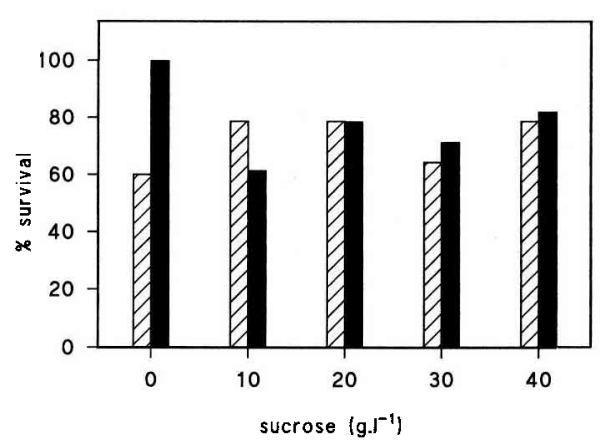

Fig 5. Effect of sucrose concentration in the rootdevelopment medium on the survival of rooted planted of 2 hybrid walnut ( $J$ nigra $n^{\circ} 23 \times J$ regia) clones after $28 \mathrm{~d}$ of acclimatization (D152 $\mathbf{E}$ and M41 $n=14$ except $0 \mathrm{~g} / \mathrm{l}, n=5$ ). No significant difference was observed with $\chi^{2}$ test at the $\alpha=5 \%$ level.

suggested that the assimilates produced by photosynthesis are not sufficient to meet the energy requirements of the root primordia, which are very high for the initiation and development of the organs. This hypothesis is supported by the results of a previous

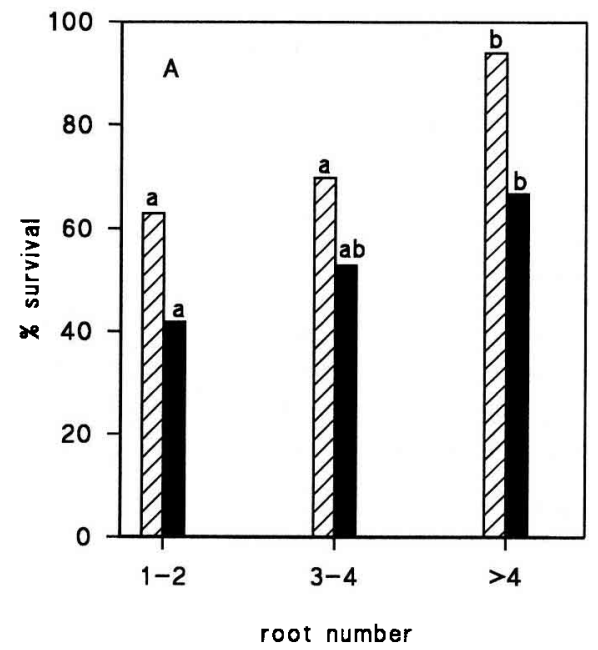

study (Thorpe and Meier, 1972). The authors observed that shoot formation in tobacco callus increased respiration as the result of the use of carbohydrate reserves in the callus as starch. Indeed, we observed an antagonism between the number of roots and the number of leaves in the walnut plantlet.

We observed that the hybrid walnut plantlets cultured on a medium with a high sucrose concentration had a high soluble carbohydrate content. It was similar to that observed in potato plantlets (Cournac et al, 1991) and in hop plants (Howard and Sykes, 1966). The high sucrose concentration also led to high dry matter accumulation in walnut plantlets but all plantlet parts were not affected similarly. The dry matter accumulation was greater in roots and callus than in the aerial part. Mousseau (1986) reported the same difference in dry matter accumulation in tobacco cultured in vitro with or without sucrose. In this species, the dry matter decrease in plantlets cultured without sucrose was not compensated for by $\mathrm{CO}_{2}$ enrichment of the atmosphere.

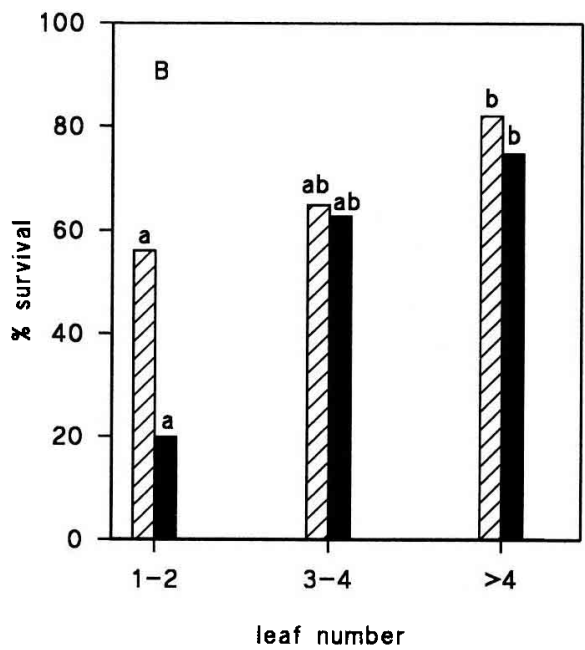

Fig 6. Relationship between the survival of rooted plantlets of 2 hybrid walnut ( $J$ nigra $n^{\circ} 23 \times J$ regia) clones M41 and D152 and initial number of roots $(\mathbf{A})$ or initial number of leaves (B) after $28 \mathrm{~d}$ of acclimatization. Values followed by the same letter are not significantly different $\left(\chi^{2}\right.$ test at the $\alpha=$ $5 \%$ level). 
The roots and the callus were favourable sites for the accumulation of soluble carbohydrates. The starch content was low compared to the soluble carbohydrate contents. Capellades et al (1991) observed that the unrooted rose shoots grown on a high sucrose concentration accumulated starch in the chloroplast and showed the highest survival rate during acclimatization. The low starch content of the rooted shoots could be due to a high degradation of carbohydrates by an intense respiratory metabolism devoted to the root growth. The good correlation between the number of roots per rooted shoot and survival of hybrid walnut could be explained by the carbohydrates stored in the roots and callus. These reserves were used during the acclimatization. Moreover, a well-developed root system improves water absorption and salt nutrition during acclimatization. The larger root system of Douglas fir plantlets absorbed more water and increased photosynthetic activity (Mohammed and Vidaver, 1991).

Despite a significant difference between the number of roots and the sucrose concentration in the root-development medium, no relationship was observed between the sucrose concentration and the survival of in vitro walnut hybrids. Thus, other factors must be involved in the survival of rooted shoots.

The number of mature leaves at transplanting seems to be an important morphological criterion in the survival of rooted shoots of hybrid walnut clones. The number of mature leaves is an indicator of both the ability of the apical bud meristem to produce new leaves during the acclimatization phase and the photosynthetic activity of leaf area. During acclimatization, the plantlet has moved up from mixotrophic status to autotrophic status. Plant autotrophy depends effectively on the appearance of new leaves adapted to the new environmental conditions (Donnelly and
Vidaver, 1984). The autotrophic status in cauliflower plantlets is only established from the second week of transfer (Grout and Aston, 1978). The growth of new organs adapted to acclimatization conditions is promoted by energy either from photosynthesis or from carbohydrates stored in the plantlet during the root-development phase.

Therefore, the survival of plantlets depends on the root system and on the stage of development of the aerial structure. The development and the morphology of the aerial structure at transplanting played a more important role than that of the root system, as previously observed in eucalyptus clones (Poissonnier et al, 1983) and Loblolly pine (Wisniewski et al, 1986). Madec et al (1979) noted that the absence of leaves was the main reason for mortality during acclimatization.

It has been observed that a low sucrose concentration in the propagation medium enhances photosynthetic ability of rose shoots (Langford and Wainwright, 1987) and consequently the establishment of photoautrophy (Leclerc and Creche, 1991) during the tissue culture. The assimilation rate observed on plantlets grown on a medium without sucrose was similar to that of seedlings (Short et al, 1987). In hybrid walnut, the absence of sucrose in the rootdevelopment medium induced a low rooting percentage, which is a real problem. Further studies are necessary to determine whether both the $\mathrm{CO}_{2}$ enrichment in the vessel and the high light intensity in the growth chamber stimulate root growth and autotrophy on the sucrose-free medium of the hybrid walnut plantlets.

\section{ACKNOWLEDGMENT}

The authors thank $\mathrm{P}$ Capelli and $\mathrm{M}$ Vandame for valuable technical assistance. We thank the European community for its financial support 
under the contract EEC AIR3 CT92-0142 which permitted us to carry out this scientific work.

\section{REFERENCES}

Boehringer (1984) Methods of Enzymatic Food Analysis Using Single Reagents. Boehringer Mannheim GmbH Biochemica, Mannheim, Germany, $79 p$

Capellades M, Lemeur R, Debergh P (1991) Effects of sucrose on starch accumulation and rate of photosynthesis in Rosa cultured in vitro. Plant Cell Tissue Organ Cult 25, 21-26

Cournac L, Dimon B, Carrier P, Lohou A, Chagvrdieff $P$ (1991) Growth and photosynthetic characteristics of Solanum tuberosum plantlets cultivated in vitro in different conditions of aeration, sucrose supply, and $\mathrm{CO}_{2}$ enrichment. Plant Physiol 97, 112117

Dickson RE (1979) Analytical procedures for the sequential extraction of ${ }^{14} \mathrm{C}$-labeled constituents from leaves, bark and wood of cottonwood plants. Physiol Plant 45, 480-488

Donnelly DJ, Vivader WE (1984) Leaf anatomy of red raspberry transferred from culture to soil. $J$ Am SoC Hortic Sci 109, 172-176

Driver JA, Kuniyuki AH (1984) In vitro propagation of paradox walnut rootstock. Hortscience 19, 507-509

Frossard JS, Friaud JF (1989) Root temperature and short-term accumulation of carbohydrates in two maize hybrids at early growth stage. agronomie 9 , 941-947

Greenwood MS, Berlyn GP (1973) Sucrose-indole-3acetic acid interactions on root regeneration by Pinus lambertiana embryo cuttings. Amer J Bot 60, 42-47

Grout BWW, Aston MJ (1978) Transplanting of cauliflower plants regenerated from meristem culture. II. Carbon dioxide fixation and the development of photosynthetic ability. Hortic Res 17, 65-71

Hasegawa PM, Murashige T, Takatori FH (1973) Propagation of asparagus through shoot apex culture. II. Light and temperature requirements, transplantability of plants, and cytohistological characteristics. $J$ Amer Soc Hortic Sci 98, 143-148

Hasegawa PM (1980) Factors affecting shoot and root initiation from cultured rose shoot tipes. $J$ Amer Soc Hortic Sci 105, 216-220

Howard BH, Sykes JT (1966) Regeneration of the hop plant (Humulus lupulus L) from softwood cuttings. 11. Modification of the carbohydrate resources within the cutting. J Hortic Sci 41, 155-1632
Hyndman SE, Hasegawa PM, Bressan RA (1982) The role of sucrose and nitrogen in adventitious root formation on cultured rose shoots. Plant Cell Tissue Organ Cult 1, 229-238

Jay-Allemand C, Cornu D (1986) Culture in vitro d'embryons isolés de noyer commun (Juglans regia $\mathrm{L}$ ). Ann Sci For 43, 189-198

Jay-Allemand C, Capelli P, Cornu D (1992) Root development of in vitro hybrid walnut microcuttings in a vermiculite-containing gelrite medium. Scientia Hortic 51, 335-342

Langford PJ, Wainwright $H$ (1987) Effects of sucrose concentration on the photosynthetic ability of rose shoots in vitro. Ann Bot 60, 633-640

Leclerc JC, Creche J (1991) Photoautotrophy established in multiple-shoot cultures of Ruta graveolens. Biol Plant 33, 135-134

Lees RP, Evans EH, Nicholas JR (1991) Photosynthesis in Clematis, 'The President', during growth in vitro and subsequent in vivo acclimatization. J Exp Bot 238, 605-610

Madec $P$, Perennec $P$, François J (1979) Une observation importante pour la conduite des cultures in vitro de pommes de terre. Pomme Terre Fr 390, 13-17

Mohammed GH, Vidaver WE (1991) Plantlet morphology and the regulation of net water loss in tissue-culture Douglas fir. Physiol Plant 83, 117-121

Mousseau $\mathrm{M}$ (1986) $\mathrm{CO}_{2}$ enrichment in vitro effect on autotrophic and heterotrophic cultures of Nicotiana tabacum (var Samsun). Photosynth Res 8, 187191

Poissonnier M, Dumant MJ, Franclet A (1983) Acclimatation de clones d'eucalyptus multipliés "in vitro". Ann Rech Sylvic (AFOCEL) 55-83

Pua EC, Chong $C$ (1985) Regulation of in vitro shoot and root regeneration in 'Macspur' apple by sorbitol (D-glucitol) and related carbon sources. J Am Soc Hortic Sci 110, 705-709

Short KC, Warburton J, Roberts AV (1987) In vitro hardening of cultured cauliflower and chrysanthemun plantlets to humidity. Acta Hortic 212, 329-334

Thorpe TA, Meier DD (1972) Starch metabolism, respiration, and shoot formation in tobacco callus cultures. Physiol Plant 27, 365-369

Wardle K, Quinlan A, Simpkins I (1979) Abscisic acid and the regulation of water loss in plantlets of Brassica oleracea $\mathrm{L}$ var botrytis regenerated through apical meristem culture. Ann Bot 43, 745-752

Wisniewski LA, Frampton LJ Jr, McKeet SE (1986) Early shoot and root quality effects on nursery and field development of tissue cultured lobolly pine. Hortscience 21, 1185-1186 